\title{
Neurolmages
}

\section{Hyperhidrosis in Parkinson disease}

Berend Feddersen, MD; Thomas Klopstock, MD; and Soheyl Noachtar, MD, Munich, Germany

We suspect that these spots (figure, A) are due to hyperhidrosis, seborrhea, and seborrheic dermatitis of the scalp in patients with Parkinson disease (PD). These autonomic symptoms are common in $\mathrm{PD}^{1}$ and cause considerable physical, social, and emotional distress. While seborrhea and "off"-period sweating may respond favorably to L-dihydroxyphenylalanine, or dopamine agonists, sweating associated with dyskinesia requires strategies to first reduce the dyskinesia. ${ }^{2}$ The efficacy of $\beta$-adrenergic blockers or local botulinum toxin injections in PD hyperhidrosis has not yet been sufficiently investigated. In the meantime, patients should be advised to avoid strenuous exercise and hot environments, wear well-ventilated clothes, and keep sufficiently hydrated. ${ }^{2}$

The authors thank Judy Benson for copyediting the manuscript.

1. Fischer M, Gemende I, Marsch WC, Fischer PA. Skin function and skin disorders in Parkinson's disease. J Neural Transm 2001;108:205-213.

2. Swinn L, Schrag A, Viswanathan R, Bloem BR, Lees A, Quinn N. Sweating dysfunction in Parkinson's disease. Mov Disord 2003;18:1459-1463.

Address correspondence and reprint requests to Dr. Berend Feddersen, University of Munich, Klinikum Grosshadern, Department of Neurology, Marchioninistr. 15, 81377 München, Germany; e-mail: feddersen@outdoorneurology.de
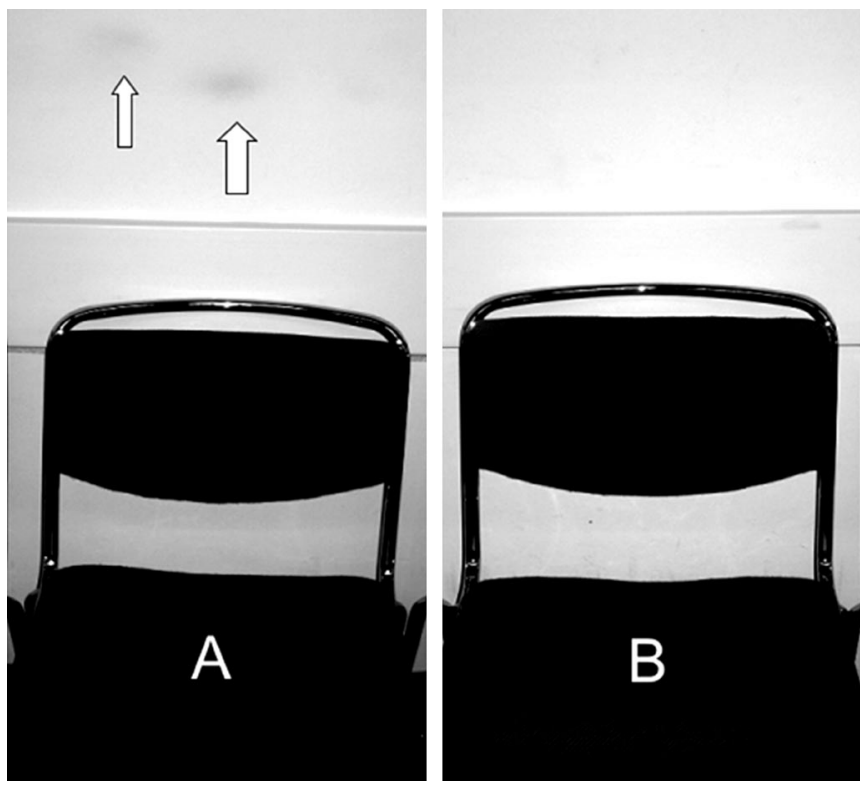

Figure. Dark spots at the height of a seated patient's head were observed on the wall above chairs reserved for patients with Parkinson disease (arrows in A) in our outpatient waiting area, but not above those for patients with epilepsy (B). 


\title{
Neurology
}

\author{
Hyperhidrosis in Parkinson disease \\ Berend Feddersen, Thomas Klopstock and Soheyl Noachtar \\ Neurology 2005;64;571 \\ DOI 10.1212/01.WNL.0000145830.94572.2E
}

This information is current as of February 7, 2005

\section{Updated Information \&}

Services

Supplementary Material

References

Subspecialty Collections

Permissions \& Licensing

Reprints including high resolution figures, can be found at:

http://n.neurology.org/content/64/3/571.full

Supplementary material can be found at:

http://n.neurology.org/content/suppl/2012/04/16/64.3.571.DC1

This article cites 2 articles, 0 of which you can access for free at: http://n.neurology.org/content/64/3/571.full\#ref-list-1

This article, along with others on similar topics, appears in the following collection(s):

Autonomic diseases

http://n.neurology.org/cgi/collection/autonomic_diseases

Parkinson's disease/Parkinsonism

http://n.neurology.org/cgi/collection/parkinsons_disease_parkinsonism

Information about reproducing this article in parts (figures,tables) or in its entirety can be found online at:

http://www.neurology.org/about/about_the_journal\#permissions

Information about ordering reprints can be found online:

http://n.neurology.org/subscribers/advertise

Neurology ${ }^{\circledR}$ is the official journal of the American Academy of Neurology. Published continuously since 1951, it is now a weekly with 48 issues per year. Copyright . All rights reserved. Print ISSN: 0028-3878. Online ISSN: 1526-632X.

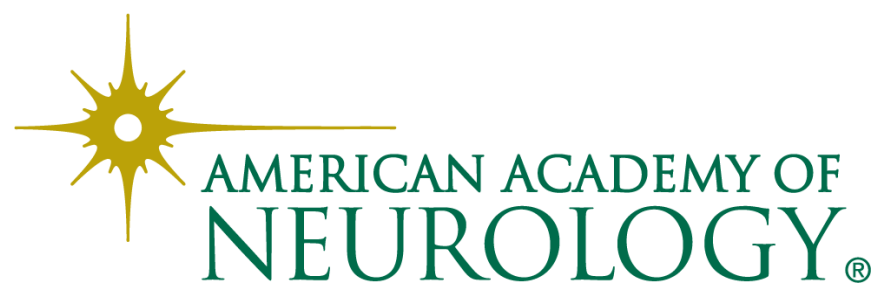

